\title{
EDUCATIONAL POLICIES FOR PROVIDING THE QUALITY OF LIFE
}

\author{
Marina Liga ${ }^{1}$, Tatiana Voronchenko ${ }^{2}$, Yelena Zakharova ${ }^{3}$
}

\begin{abstract}
Quality of life is an essential parameter to consider when society and its members are concerned. Education can become crucial in assessing social progress and quality of life. Thus, quality of life, as an indicator of any country's educational system and its efficiency, becomes an instrument for implementing educational policies both for social and personal development. Further, quality of life, a person's satisfaction with his or her life activity, is determined mostly by the state of the educational system and by conditions created for a person's development and realization of talents. Our research question is "what is considered to be qualitative, material or morality? Culture-centric or universal?”

This article aims to address the problem using systemic, structural, functional, and cultural approaches. Systemic approach helps to reveal the integral character of the studied phenomenon-quality of life. The approach, based on cultural study, helps to ground the culture-centric educational principle as a mechanism to provide adequate quality of life in contemporary society. Functional and structural approach helps to investigate the function of education and its role in the society. The change from technogenic civilization toward quality-oflife civilization requires a new perspective, which is capable of not only an adaptation to existing reality, but also of an ability to improve upon it. People who can achieve this become representatives of a new social groupmeritocracy. Culture-centric educational principle is one of the ways to build up a new educational paradigm in order to prepare young people for a contemporary society.
\end{abstract}

JEL Classification Numbers: I2, I21, DOI: http://dx.doi.org/10.12955/cbup.v2.460

UDC Classification: 3, 37

Keywords: education, quality of life, society, values, assessment, subjectivity, culture-centric

\section{Introduction}

At the beginning of the $20^{\text {th }}$ century, an English economist and representative of Cambridge University, Arthur Cecil Pigou, introduced the term “quality of life” (Pigou, 1985). Quality of life is a special work type, environmental conditions, and interaction with other people, social position, living conditions and safety.

The term was introduced into politics by the American President John F. Kennedy. He formed a social order to scientifically address the issue, "quality of life should include an opportunity to educate oneself, develop one's abilities, and preserve physical and mental health in freedom and justice" (Bestuzhev-Lada, 1993). In 1964, President Lyndon B. Johnson also referred to the term. He mentioned that Americans had already reached a high level of material welfare and it was time "to measure American society's goals not by the size of our bank deposits but rather by our people's quality of life” (Popov, 1977).

At the end of the $20^{\text {th }}$ and the beginning of the $21^{\text {st }}$ century, the governments proclaimed that reaching a worthy standard of living should be a preferred direction in contemporary states development. Quality of life has become an indicator of social, scientific, and technological progress, and an indicator of well-being in different spheres of people's activity.

“The Russian Federation Strategy of National Security till 2020" points out that it is reaching an acceptable quality of life for the citizens that the Russian Federation is concentrating its efforts on, by guaranteeing personal safety and high standard life support.

There are various definitions for the term "quality of life" in contemporary science. In post-industrial society conception of Aron (1966), Bell (2008), Brzezinski (2007), Galbraith (1958), and Toffler, 1990), quality of life is a set of material and intellectual wealth provided for citizens. Aron (1992)

\footnotetext{
${ }^{1}$ Marina Liga, Zabaikalsky State University, Russian Federation, m-liga@inbox.ru

${ }^{2}$ Tatiana Voronchenko, Zabaikalsky State University, Russian Federation, tavoronch@mail.ru

${ }^{3}$ Yelena Zakharova, Zabaikalsky State University, Russian Federation, aglena_72@mail.ru
} 
considered quality of life as "the growth of individual income and its proportional spending for articles of consumption, luxury goods (or close to luxury) and finally for such non-material things as personal services, culture, spare time.” In information society conception of Castells (2000), Martin (1996), Masuda (1980), and Naisbitt (1993), quality of life is related to information and forms of its exploitation. Castells (2000) named the forming society network because "it is created by nets of production, power and experience, which form the culture of virtuality in global streams crossing time and space.” Risk society conception of Beck (2000), Bernstein (1996), Giddens (2013), and Meshavkina (2006) interrelates quality of life and the level of risk-genuity in society. Beck's risk society conception (Beck, 2000) includes several statements, firstly, understanding the extent of risk and information has great meaning. Secondly, the growth of risks causes socially dangerous situations. Thirdly, the industrial society, oriented toward satisfaction of constantly renewing needs, creates dangerous situations and negative political potential for the risk society. Lastly, the only one who knows the risks can prevent them. Alternative civilization society conception of Bestuzhev-Lada (1993) and Diligensky, (1991) proves that it is possible to reach a worthy level of life quality only if society aims at qualitative not quantitative growth, which implies changing in conditions, principles, and the purport of existence. The individualized society conception of Bauman (2001) refers to quality of life as personal desires, interests, needs, zest for successful present life, and no concern for tomorrow. Some scientists, representatives of vital forces, personality individual, and social subjectivity conception define quality of life as a social subject's assessment of his own vital forces development, i.e. a degree of a person's self-realization in different vital activities. Personal needs and degree of their satisfaction are some forms of such assessment.

An issue of what technologies and strategies should be used to raise quality of life has become very important in contemporary society. Education is perceived as one of such technologies.

Education helps people to take competent decisions on receiving information, developing cognitive and social emotional abilities, such as flexibility, self-efficacy, and social skills as well (Organization for Economic Co-operation and Development, 2010).

Educational and intellectual potential of a person, nation, and country has come to take the place of natural and geographic conditions, and material values as a factor for stimulating and defining socioeconomic development vector and tempo.

\section{Meritocracy}

An appearance of a new social group "meritocracy" proves the paramount importance of knowledge for social development. Machlup (1962) called meritocracy "a class of intellectuals." Galbraith (1958) called it "a techno-structure.” Toffler (1990) called it "adhocracy.”

Logically, society is meritocracy for an American sociologist, D. Bell (Bell, 2008). It becomes evident that "in modern world meritocracy, indeed, when based on education, becomes functionally imperative. People, who want to correspond to modern professional standards, need high qualifications. Economic and social efficiency shows that the key social positions are no longer determined by family and birth. Now, the first criterion in social choice is education: achievements overweight what seemed to be predestined," as suggest by Lareau and Conley (Lareau \& Conley, 2008).

Such countries as Japan and South Korea, with no natural resources, relied on education and scientific potential and became leaders in the world socioeconomic development. Japan's economic development after World War II was focusing on educational potential and the use of intellectual resources. Masanori (1993) pointed out three factors, which fostered success of Japanese firms: investigations, innovations, and investments (the three “Is"). Among those factors determining Japan's 
success in their postwar era, Drucker (1999) mentioned readiness to accept and adapt to its needs, the system of management, and, in the first place, technical-vocational system of education. For only 20 years (from 1950s to 1970s), after American occupying force had left its territory Japan became the second world leader in economic power and technological expansion. After the war in Korea at the beginning of 1950s, the Southern part of the peninsula was destroyed even more than Japan. During the previous epochs, Korea was a backward country. Aside from 35 years of its occupying period, the Japanese were suppressing any entrepreneurial activity and aspiration of getting higher education. However, young and talented people who received their education in American Universities effectively started implementing scientific principles, they had learned, in management. Therefore, South Korea quickly became a highly-developed country in just 20 years (Drucker, 1999). Modern society is a "knowledge society," in which education becomes a social value, and knowledge is a symbolic capital. Knowledge, as capital, differs from other riches in its one aspect-it is inexhaustible. It never runs out when people use it; knowledge is a "collective commodity" (Bell, 2008). Education becomes a means of experience and knowledge translation. It influences moral changes in personal and social life, shapes new values and ideologies, known as "post-materialistic."

Defining the role of education in modern world and in a person's life, one of the leading sociologists Talcott Parsons (Parsons, 2013), pointed out that only education can transform society, reduce diktat of spontaneous market and bureaucracy, and raise adaptability of society.

Addressing analysis of issues concerning economic growth in needy countries, Paul Samuelson (Samuelson, 1972) stressed that these countries do not need to look for "Contemporary Newtons." Needy nations can solve their problems by borrowing technologies invented by other countries. The main condition for countries to grow economically quickly is associated with education, preparation for modern specialists, and capability of implementing these technologies.

\section{Social structure}

According to Beck (2000), education can change the social structure, "disintegration of the social structure with traditional stratification takes place. People become free of hierarchies and choose themselves their own life styles.”

A new social layer of meritocracy appears. Meritocracy characteristics are: high educational level, employment in high-tech industries, and preference for working with knowledge and information; creativity, high property status; ability to realize one's own plans, self-development and selfrealization; ability for reproduction, self-reliance in social activities. The power of this class is based on knowledge monopoly rather than on wealth and property. They can produce knowledge independently of other members of the society, thus becoming free from other social groups. We can characterize them as the social group of wage workers, part of whom are middle class, who are concerned with their professional education and living standards. This group includes scientific workers, technical and engineering employees, administrative staff, peasantry, farmers, highlyqualified workers, and service employees. The social structure can change and is flexible depending on one's qualifications. The same social group of wage workers can be low-qualified and nonqualified labor. It includes those whose intellectual abilities were depreciated by modern technical labor management. These people are not trade union members and do not belong to a certain class group, and are always under the threat to lose their work. In fact, they are lowly educated, materially oriented, and are engaged in primitive service industries.

The German sociologist, Ulrich Beck (Beck, 2000), explained the interconnection between education and social structure. He suggested the following: 
- significant improvement of economic condition for the greater majority of population eliminates the differences between representatives of various social groups in terms of their opportunities and life style. Theoretically, a worker and the business owner can drive the same car and stay at the same resort;

- material welfare is subjectively considered as an individual achievement, even if society plays an important role. Wherein social identity individualization and weakening of its stratified dependency take place;

- diversification and individualization of vital forms take place, conditioned by the growing social mobility opportunities;

- the social structure, built according to former stratification model, collapses. People get rid of hierarchization and choose their own lifestyles.

The aforementioned statements proved the importance of education as one of the mechanisms of reaching a worthy quality of life. Shaping a "person of knowledge" requires reorganizing the whole educational system. The main educational task is not to equip learners with the system of knowledge, but to teach them of ways to learn.

\section{Educational Content}

Social structure evolution proves that education is one of the mechanisms to reach a worthy quality of life. Formation of a "man of knowledge" demands restructuring of the whole educational system. The main educational task is not to provide a system of knowledge, but to teach them how to study.

The psychologist, Herbert Gerjuoy (Gerjuoy, 1970), wrote that "New education must teach an individual to classify and reclassify the information, to assess its credibility, change categories if necessary, to associate from concrete to abstract and vice versa, to change viewpoints dealing with problems, to engage in self-educating process. Tomorrow's illiterate will not be the man who can't read; he will be the man who has not learned how to learn."

Education should consider such components of social development as anthropocentrism, democratism, humanism, and immaterialism. It is necessary to pay attention to the development of the learner's personal potential when choosing educational content, as education should not focus only on a certain amount of knowledge, even if they may appear to be new and urgent. It is important to include things that help bringing up emotional and affective attitude toward the world, shaping moral values and norms, and determining activity strategies in all diverse life situations. Such problems include: detecting demand for traditional and new professions; elaborating assessment means to reveal efficiency and necessity to replace traditional jobs by new ones; evaluating the process of statistical data formation about the state and tendencies of specialists' demand in all spheres of social activity; conceptual grounding of strategy and methods of expertise in measuring demand for traditional and new jobs; studying international experience in the field of retraining, developing vocational competence of specialists relevant to transformation of modern social structure; finding out and explaining the necessity to correlate professional tasks for specialists with the qualifying criteria as defined according to the Federal State Educational Standard of Higher Professional Education of the third education (Russian Federation Ministry of Education and Science, 2012).

Education determines a person's social status, his place in the social structure, level of his needs satisfying, ability to reproduce and perfect his sap, as well as individual and social subjectivity. It is the factor that defines social well-being of a person and family, successes, and professional credentials. A person can attain a worthy lifestyle only through life-long study, when taking intellectual initiative and social intellect, necessary for realizing professional activity at a certain 
period. Among other characteristics, which allow a person to reach a worthy quality of life, one can also refer to a high level of intellectual preparedness for self-study, self-education, self-development, and professional retraining.

Quality of life requires quality of education, its priorities, and main directions of development. In its turn, education also determines quality of life through such components as: the level of economic development, the quality of public health, the quality of culture, and social politics. High level quality of education forms such a lifestyle, which demands new needs and values.

To provide a worthy quality of life, a person should gain from education: a high level of upbringing; culture; developed personal qualities, (managerial abilities, self-reliance in taking decisions, and sense of responsibility for one's actions), necessary for living in a constantly changing world; a high level of professionalism (open-mindedness and intelligence), which allows one to make creative decisions in diverse activity spheres. The growth of educational quality level will improve socioeconomic position of the country in the world and ensure that its citizens reach the appropriate quality of life.

The change of value priorities in social development, alteration of conditions and ways of activity, use of new resources (intellectual technologies and knowledge), and providing social well-being increases the significance of education in contemporary world. The change of technogenic civilization to quality-of-life civilization requires bringing up quite a different perception, which is capable of realizing professional activity in changing conditions, influencing the current situation, changing and modifying its state and development, and remaining detached to a particular field of specialization. Only if a person possesses a free intellectual life and knows cultural values, he or she is able to create a new social experience, scientific theories, and conceptions.

In many educational conceptions, one of the main tasks is forming a personality capable of adapting to the changing world and acquiring existing forms of activity. But, a person must be able not only to adapt to surroundings, but also to change it. It is possible only if there are creative personalities in society, aiming toward self-development of their talents, and searching for new forms of life activities. The choice between reproductive and creative behavioral type depends on the person and on the goals and tasks set by educationalists.

At present, educationalists have a task of defining what a person of the new civilization should be like; what a person of the new contemporary society requires; what is this new personality type; and what are mechanisms of forming a personality for contemporary society.

In the society, which is constantly changing, the significance of learning skills to transform an individual's activity becomes important. Education performs an adaptive function-a person's adaptation to professional and social changes.

Satisfying material needs generates new needs of higher demands, stimulating economic growth, which demands new things from a person. The basis for economic development is to master the existing and to foster the appearance of new technologies. Its creation and exploitation will depend on intellectual, moral, and non-material needs of a person.

Educational sphere in a contemporary society, crossing economic sphere and educational activity, becomes a major component for economic growth. Economics and education are two interrelated elements of a social system, conditioning its dynamic development. The mechanism of interaction of education with quality of life can be explained in the following way: education through socialization of a personality develops creativity, forms high level of communicative abilities, social competencies, and tolerant attitudes. It is the factor, which provides for many aspects of life quality. 


\section{Culture-centricity of education}

"Culture-centricity is to solve all the problems, connected with presenting various cultures, to eliminate polarity," (Kuo \& Chew, 2009). However, in our opinion, education will help to reach a worthy quality of life only if its main principle is culture-centric. The principle of culture-centricity of education will allow a subject to form and successfully realize programs of one's own life activity, and to define mechanisms and methods of achieving them. Culture-centricity-oriented education does not only open great opportunities to study cultural treasure, but also forms a person's vector of interests, needs, and perception of the world.

Culture-centricity is the basis on which a person can form professional competency, change social status, and reach a worthy quality of life. Thus, culture-centric education will promote modernization of one's mind, innovative thinking formation, and realization of personal creativity potential.

The necessity to make education culture-oriented is connected with the fact that education draws its content from culture and scientific knowledge, whereas culture reproduces values significant to social norms, supports samples of human activities, and determines principles of personal introduction into society. To our understanding, culture-centricity addresses the study of cultural fundamentals of a person's life activity (norms, values, meanings, behavior types, traditions, and ideals), and influences development within the existing sociocultural frames of reality.

The purpose of a new educational paradigm, connected with the evaluative attitude towards man, is the formation of aspiration for self-realization, self-development, and self-regulation.

\section{Educational process}

Within culture-centricity-oriented paradigm, all components of educational process are supposed to change: the teacher, the student, knowledge content, results of educational activity, etc. The teacher's role to transmit ready and adapted knowledge disappears. Instead the teacher becomes a mentor and guides the students to attain the knowledge themselves. The student is supposed to acquire knowledge through the process of creative search; he or she is the subject of educational activity. The purpose of education is to form a creatively active person, possessing a definite sum of knowledge and a set of skills and abilities, which will allow the person not only to adapt in the dynamically developing social space, but also to change it.

\section{Conclusion}

In relation to the aforementioned, the function of education is to introduce a person to a proper life process, which means mastering in self-development and self-education. The dominating reasons of culture-oriented paradigm are different. Education is thought of as a mutual process of teacher-andstudent reality learning. Knowledge is of ambiguous, inaccurate character; the student takes an active part in processes of its understanding and acquiring.

On the one hand, life quality is a secondary phenomenon in relation to education as it reflects all norms and values, formed in educational process, presents practical realization of all that is given to a person through education. On the other hand, life quality is also the fruit of the subject's activity, professional, and personal achievements.

In this article, we have stated that there are definite interrelation between quality of life and quality of education, which are as follows:

- quality of life determines quality of education, its priorities and main directions of its development; 
- education determines quality of life through such components as economy development level, quality of public health, quality of culture, and social policies;

- high level of educational quality conditions form such quality of life, which creates conditions for new values and needs;

- quality of life and education can provide a person with a certain position in the social structure, access to realize oneself in various roles, and mobility to solve collective goods problems;

- education forms competencies, which allow a person to attain better quality of life.

The main indicators for assessing an effective interrelation between quality of life and education are:

- appearance of a new class-meritocracy;

- culture-centricity orientation of education;

- personal satisfaction with one's profession.

Furthermore, at present, using Russia as an example, we cannot say that the mentioned regularities are fully realized. Meritocracy is only in process of developing. Education is not a social mobility lift, but it is a lift, guaranteeing a worthy quality of life.

\section{References}

Aron, R. (1992). Etapy razvitiya sotsiologicheskoy mysli [Main Currents in Sociological Thought]. Moscow: Progress.

Aron, R. (1966). Peace and war. A theory of international relations, 373-403.

Bauman, Z. (2001). Identity in the Globalizing World. Social Anthropology, 9(2), 121-129.

Beck, U. (2000). Risk Society: Towards a New Modernity (V. Sedelnikov, \& N. Fyodorova, Trans.). Moscow: ProgressTradition. (Original work published 1992).

Bell, D. (2008). The Coming of Post-Industrial Society. New York: Basic Books. (Original work published 1973).

Bernstein, P. L. (1996). Against The Gods: The Remarkable Story of Risk. New York: John Wiley \& Sons.

Bestuzhev-Lada, I. V. (1993). Prognoznoye obosnovaniye sotsial'nykh novovvedeniy [Prognostic Study of Social Innovations]. Moscow: Nauka

Brzezinski, Z. (2007). The grand chessboard. Basic Books.

Castells, M. (2000). Informatsionnaya epokha: Ekonomika, obshchestvo, kul'tura [The Information Age: Economy, Society and Culture]. Moscow: GU VSHE.

Drucker, P. F. (1999). Post-Capitalist Society. In V. L. Inozemtsev (Ed.), New Post-Industrial Wave in the West: Anthology (pp. 67-101). Moscow: Academia.

Galbraith, J. K., \& Crook, A. (1958). The affluent society, 534. Boston: Houghton Mifflin.

Gerjuoy, H. (1970). In A. Toffler (Ed.), Future Shock (pp. 414). New York: A Bantam Book, Random House.

Giddens, A. (2013). The third way: The renewal of social democracy. John Wiley \& Sons.

Kuo, E. C., \& Chew, H. E. (2009). Beyond ethnocentrism in communication theory: Towards a culture-centric approach. Asian Journal of Communication, 19(4), 422-437.

Lareau, A., \& Conley, D. (2008). Social Class: How Does It Work? Russell Sage Foundation.

Machlup, F. (1962). The production and distribution of knowledge in the United States, 278. Princeton university press.

Martin, W. J. (1996). Global information society. Ashgate Publishing Company.

Masanori, H. (1993). Aspects of labor market adjustments in Japan. Journal of Labor Economics, 11(1), 136-61.

Masuda, Y. (1980). The information society as post-industrial society. World Future Society.

Meshavkina, N.A. (2006). Vliyaniye otnosheniya k risku na prinyatiye resheniy [The Influence of the Attitude Towards Risk On the Making Decisions]. Vestnik Bashkirskogo Universiteta, (4), 179-180.

Naisbitt, J. (1993). Global Paradox: The Bigger the World Econmy, the More Powerful Its Smallest Players. William Morrow \& Co., Inc.. 
Parsons, T. (2013). Social System. Routledge.

Pigou, A. C. (1985). The Economics of Welfare. Moscow.

Popov, S. I. (1977). Problema "kachestva zhizni” v sovremennoy ideologicheskoy bor'be [Quality of Life Issue in Modern Ideological Struggle]. Moscow: Politizdat.

Organization for Economic Co-operation and Development (2010). Improving Health and Social Cohesion through Education. OECD.

Russian Federation Ministry of Education and Science of Russian Federation (2012). Federal'nyye gosudarstvennyye obrazovatel'nyye standarty [Federal State Educational Standard of Education]. Retrieved from http://fgosvo.ru/fgosvpo/7/6/1

Samuelson, P. A. (1972). Economics in a golden age: a personal memoir. The Twentieth Century Sciences: Studies in the Biography of Ideas. New York: W. W. Norton.

Toffler, A. (1990). Future Shock. Random House LLC. 